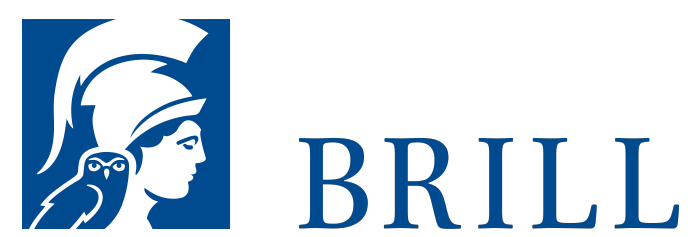

\title{
Nomina sacra in the Greek papyri of the first 5 centuries A.D.
}

The sources and some deductions

Author: Paap

\author{
Language: \\ English \\ Subjects: \\ General, \\ Classical Studies \\ Publisher: Brill \\ Series: \\ Papyrologica \\ Lugduno- \\ Batava, Volume: \\ 8 \\ E-Book (PDF) \\ Released online: \\ o8 Jun 2020 \\ ISBN: $978-90-$ \\ 04-42998-7 \\ List price \\ USD Â $\$ 42.00$ \\ Hardback \\ Publication date: \\ o1 Dec 1959 \\ ISBN: 978-90- \\ O4-42883-6
}


For more information see brill.com

Order information: Order online at brill.com +44330 333 0049 | customerservices@brill.com Submission information: brill.com/authors

Titles published by Brill | Fink, Brill | mentis or Brill | Schöningh: +49(o)715413279216| brill@brocom.de 